\title{
Influence of internal and macro factors on profitability of Indian commercial banks: empirical study
}

\author{
Karrar Khalaf Allamy¹, Ahmad Moh'd Mansour², Anwar Ahmad ${ }^{3}$, Eissa A. Al- \\ Homaidi $^{4}$ \\ ${ }^{1}$ Research Scholar, Department of Commerce, Delhi University, Delhi, India. \\ ${ }^{2}$ Assistant Professor, Business Department, Faculty of business, Al-Balqa Applied University, Jordan \\ ${ }^{3}$ Assistant Professor, Department of Commerce, Aligarh Muslim University, Aligarh, India. \\ ${ }^{4}$ Research Scholar, Department of Commerce, Aligarh Muslim University, Aligarh, India.
}

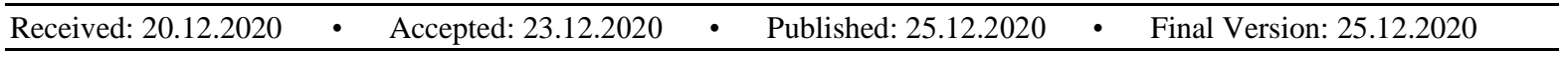

\begin{abstract}
This review aims to study the influence of financial performance in commercial banks in India. The article used descriptive analysis, correlation matrix, and regression analysis. The results showed that firm size, capital adequacy, deposit, and inflation rate have a strongly significant influence on financial performance, while gross domestic product (GDP) has no significant impact on return on assets. The outcomes also indicated that firm size (LOGAS), capital adequacy (CA), and deposit (DP) have a negative influence on financial performance, whereas macroeconomic features as GDP and rate of inflation have a positive effect on return on assets of the current investigation. This article bridges the existing gap in the financial performance and profitability of Indian banks during the period of the study. This study also very important for users, analyses, investors, academicians, and research scholars.
\end{abstract}

Keywords: financial performance; external factors; commercial banks; India.

\section{Introduction}

In the financial system and the economy, commercial banks are major big banks. They rule framed deposits and lending and to provide the public with other facilities. By influencing borrowers (savers) and lenders (investors), these institutions turn a profit. Banks play a key role as financial intermediaries in the activity of most countries. Banks need a good leadership team to allow them to dissociate among liquidity, sophistication, and risk priorities at various levels. As such, financial institutions must be able to determine the financial health of a borrower and measure projects if they are to remain profitable (Ilhomovich, 2009). With a stable financial structure characterised by a diversified portfolio of banking firms, "India is one of the biggest countries in the South Asia region" (Ghosh, 2016). Presently, India is among the world's fastest-growing economies. In India, there are several bank entities and they perform various tasks in the sense of economic operations. Due to higher "Gross Domestic Product" (GDP) growth rates, banking sector has gained more attention lately.

India made substantial progress in the performance and effectiveness of its financial sector in the early 1990s (Ghosh, 2016). Since 1991, other major industries have added to and funded the Indian economy (Singh et al., 2016). Indian financial system is a mixture of commercial societies that are public, private, international, regional, industrial, urban cooperative, and industrial (Shrivastava et al., 2018).

\footnotetext{
* Corresponding Author: eissa.alhomaidi2020@gmail.com
} 
The financial system is regulated by banks in india and they play a major role in economic growth. Financial institutions should efficiently plan their asset allocation to improve their profitability, "taking into account the vibrant, competitive Indian environment" (Viswanathan et al., 2014).

This analysis is intended to research the effects of the financial profitability of commercial banks in India from 2008 to 2017. Descriptive analysis, a matrix of correlation, and regression analysis were used in the research. The financial output described by return on assets (ROA) is considered a dependent factor, while the size of the financial firm (LOGAS), the capital adequacy ratio (CA) and the deposit ratio (DP) are considered internal, whereas the gross domestic product (GDP) and inflation rate are external parameters. This article bridges the existing gap in the financial performance and profitability of Indian commercial companies during the period of the study. This study also very important for users, analyses, investors, academicians, and research scholars.

This article structured as follow. Section one presents the introduction of the present review, section two offers the review of literature of the current investigation, the third section shows the methods used in this article, section four demonstrates the data analysis and results, finally section five presents the conclusion of the current study.

\section{Literature review}

Several epidemiological studies analyzed the relative performance determinants in various countries such as (Almaqtari et al., 2019) reported that bank size, branch number, wealth management ratio, operational quality, and "leverage ratio are the most significant bank-specific factors that affect Indian commercial banks profitability as measured by Return on assets". In addition, the outcomes showed that bank size, asset management ratio, asset quality ratio, and liquidity ratio were considered to have a strong positive effect on ROE among bank-specific factors. As far as the main banks are concerned, the findings showed that inflation, exchange rate, interest rate, and demonization had a major effect on ROA. A significant link between multiple packets (e.g., "security trading, hedge funds, foreign exchange, insurance, etc".) and productivity has been established by Saona (2016) a. negative correlation between revenue diversification (e.g., interests, taxes, fees, etc.) and competitiveness, a significant link between capital structure and profit margins. Al-Homaidi, Tabash and Ahmad (2020) found that the banking sector's history, details on CG, corporate social transparency, size of the company, and age of firm have a detrimental and substantial connexion with asset return. With regards to ROE, the results show that the banking sector's history, profitability statements, executive compensation data, corporate social reporting, zakat data, and bank size have a negative and substantial impact on return on equity. The ratio of equity to total assets is determined by the appropriateness of capital. It is an important ratio that decides capital power (Abel \&, Roux (2016).

Al-Homaidi et al. (2018) found that, as calculated by all bank-specific variables exhibited significant effects on competitiveness, excluding the number of branches. The outcomes also suggest that all the main banks used in the study are shown to be relevant to adverse effects on the profitability of Indian commercial banks. The ratio of total deposits to total assets was widely used in previous studies by Acaravci and Calim (2013) as an indicator of the deposit ratio. Al-homaidi et al. (2019) noticed that all external influences (Gross domestic product (GDP), exchange rate $(\mathrm{EXCH})$, and interest rate (INTRT) have a negative influence on the profitability of listed banks in India, other than that the INF rate has a significant impact on firm profitability of banks. Al-Homaidi, Tabash, Allamy and Ahmad (2020) reported that Tadhamon Islamic International Bank (TIIB) achieved the highest easygoing index score over the 10 years, Saba financial institution (SIB) obtained the second-highest average disclosure score, and Shamil Bank of Yemen \& Bahrain got the best overall disclosure rating score during the 10 years surveyed. As a proxy for calculating bank size, AL-Omar and AL-Mutairi (2008) using total assets. Alhomaidi et al. (2019) found that the size of the management, management diligence, size of the audit committee, and institutional ownership has a big effect on ROA, while the composition of the board, composition of the audit committee, diligence of the audit committee, and age of the company have an insignificant impact on ROA. Al- 
homaidi et al. (2019) indicated that the basic internal factors that affect the liquidity of Indian listed companies are return on assets and firm age.

The effect of exports or imports on the productivity of thirty-seven commercial banks in India was investigated. The results demonstrate that "size of firm, quality of assets, liquidity, management of assets, and net interest margin" are significant internal factors affecting ROA. It is found that capital adequacy, deposits, "quality of operations, gross domestic product and inflation rate have a major negative effect on ROA". The findings also suggest that the adequacy of capital, bank size, efficiency of operations, GDP, and rate of inflation have a major negative effect on ROE (Al-homaidi et al. 2020).

Yahya, Akhtar, and Mosab (2017) examined the effect on the profitability of Islamic banks in Yemen of political instability, macroeconomic and internal indicators. The findings of the analysis suggest that there are negative and relevant associations with ROA and ROE between operational efficiency and financial risk. The results also indicate that capital adequacy has a negative and marginal correlation with ROA and ROE. In addition, the report shows that the size of assets $(\log \mathrm{A})$, wealth management, funding, and reserves have a positive and significant impact on the financial performance of banks. Gross domestic product (GDP) and inflation rate (INF), and political uncertainty have had a positive and important influence on the value of Yemeni companies. To check if bank-specific and external predictors have an effect on the profitability of Financial institutions in selected countries in different regions. The findings of the analysis suggest that institutions with larger asset sizes and better management tend to greater asset returns. Value/originality (Masood \& Ashraf, 2012). AL-Omar and AL-Mutairi (2008) found that equity ratio, loan-asset ratio, operating expense ratio and total assets were seen to explain about 67 percent of the difference in asset return (ROA). It indicated that internal factors (with the exception of borrowing costs) and economic indicators (with the exception of joblessness) greatly impact firm liquidity. This included the size of the company, deposits, productivity, adequacy of capital, GDP and inflation. Furthermore, it was concluded that bank size and GDP had a negative impact on bank liquidity. But on the other hand, a positive impact on bank liquidity was demonstrated by deposits, productivity, capital adequacy, and inflation (Singh \& Sharma, 2016).

\section{Research methodology}

The study collected the data from the annual reports of 35 financial banks in India for the period from 2008 to 2017. This study is based on secondary data. The aim of this investigation to identify the determinates of the financial firms in India by using the financial ratios in the study. The study used descriptive analysis, correlation matrix, and regression analysis. The results also found that there is no multicollinearity diagnosis between variables of the current investigation.

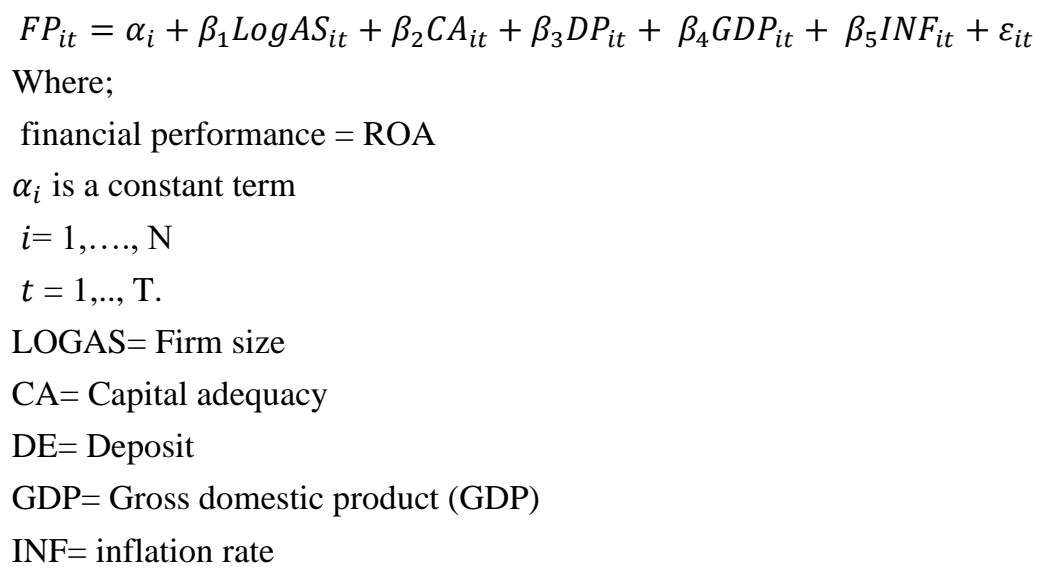




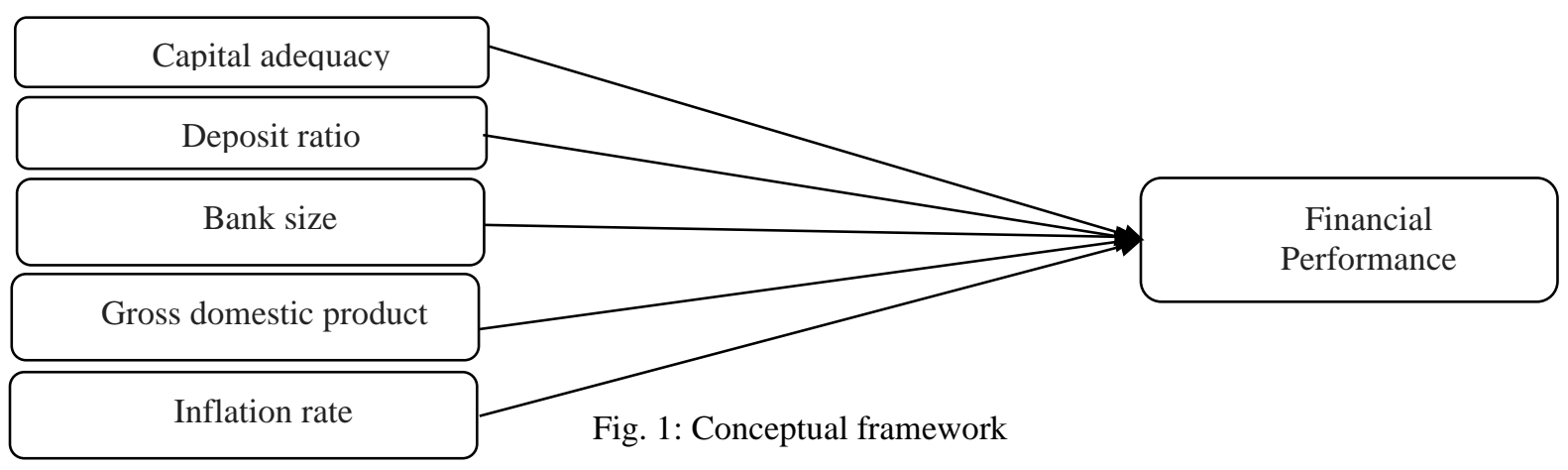

\section{Analysis and discussion}

\subsection{Descriptive statistics}

Table 1 demonstrates the outcomes of descriptive of the present investigation in commercial banks in India for the period from 2008 to 2017. The outcomes present that return on assets (ROA) has mean value is -0.188686 , Median is 0.004975 , Maximum is 0.703098 , Minimum is -3.912023 , and Std. Dev. is 0.657033 respectively. While size of firms, capital adequacy, deposit, gross domestic product (GDP), inflation rate has mean values $(13.89187,0.005095,0.819724,7.331000,8.390000)$, median value is $(14.05682,0.003308,0.852684$, $7.145000,8.600000)$, maximum values are $(17.11504,0.070888,0.915504,10.26000,12.00000)$, minimum values are $(9.600529,0.000000,0.521965,3.890000,4.900000)$, and Std. Dev. values are $(1.280058,0.007621$, $0.082388,1.813405,2.305921)$ respectively.

Table 1. Descriptive statistics

\begin{tabular}{lcccccc}
\hline \multicolumn{1}{c}{ Variable } & ROA & LOGA & CA & DP & GDP & IFR \\
\hline Mean & -0.188686 & 13.89187 & 0.005095 & 0.819724 & 7.331000 & 8.390000 \\
Median & 0.004975 & 14.05682 & 0.003308 & 0.852684 & 7.145000 & 8.600000 \\
Maximum & 0.703098 & 17.11504 & 0.070888 & 0.915504 & 10.26000 & 12.00000 \\
Minimum & -3.912023 & 9.600529 & 0.000000 & 0.521965 & 3.890000 & 4.900000 \\
Std. Dev. & 0.657033 & 1.280058 & 0.007621 & 0.082388 & 1.813405 & 2.305921 \\
Skewness & -1.492933 & -0.493950 & 5.428594 & -1.614655 & -0.101249 & 0.047905 \\
Kurtosis & 6.562422 & 3.285777 & 39.76677 & 5.013690 & 2.465641 & 1.664723 \\
Obs. No. & 370 & 370 & 370 & 370 & 370 & 370
\end{tabular}

\subsection{Correlation matrix}

Table 2 presents the outcomes of the current review about the commercial banks in India. The results of the present investigation indicated that there is a high correlation between RON and rate of inflation (IFR). The findings also revealed that return on assets has a positive correlation with capital adequacy, gross domestic product (GDP), and inflation rate, while it has a negative association with bank size and deposit. The results also found that there is no multicollinearity diagnosis between variables of the current investigation. 
Table 2. Correlation matrix

\begin{tabular}{lcccccc}
\hline Variables & LNROA & LOGA & CA & DP & GDP & IFR \\
\hline LNROA & 1 & -0.10555 & 0.003045 & -0.32199 & 0.034876 & 0.167101 \\
LOGA & & 1 & -0.60741 & -0.12688 & -0.05649 & -0.10561 \\
CA & & & 1 & -0.18602 & 0.032989 & 0.029114 \\
DP & & & & 1 & 0.007188 & -0.00561 \\
GDP & & & & & 1 & 0.105799 \\
IFR & & & & & &
\end{tabular}

\subsection{Regression analysis}

Table 3 shows the outcomes of the regression between financial performance and internal and external characteristics of the current examination. The results show that the independent variable contributed about 0.174541 from the financial profitability calculated by return on assets (ROA) for the period from 2008 to 2017 . The outcomes indicated that firm size (logas), capital adequacy (CA), deposit (DP), and inflation rate have a strongly significant influence on financial performance of India banks, while gross domestic product (GDP) has no significant influence on return on assets. The outcomes also indicated that firm size (LOGAS), capital adequacy (CA), and deposit (DP) have a negative effect on profitability, whereas macroeconomic features as gross domestic product (GDP) and inflation rate have a positive impact on return on assets of the current investigation.

Table 3: Multiple regression analysis

\begin{tabular}{lcccc}
\hline Variable & Coefficient & Std. Error & t-Statistic & Prob. \\
\hline C & 4.348005 & 0.686784 & 6.330960 & $0.0000^{* * *}$ \\
LOGA & -0.153446 & 0.032351 & -4.743149 & $0.0000^{* * *}$ \\
CA & -22.31645 & 5.453225 & -4.092340 & $0.0001^{* * *}$ \\
DP & -3.248993 & 0.403678 & -8.048475 & $0.0000^{* * *}$ \\
GDP & 0.005336 & 0.017252 & 0.309321 & 0.7573 \\
IFR & 0.039669 & 0.013644 & 2.907484 & $0.0039 * * *$ \\
"R-squared & 0.185726 & "Mean dependent var & -0.188686 \\
Adjusted R-squared & 0.174541 & S.D. dependent var & 0.657033 \\
S.E. of regression & 0.596945 & Akaike info criterion & 1.822101 \\
Sum squared resid & 129.7091 & Schwarz criterion & 1.885563 \\
Log-likelihood & -331.0887 & Hannan-Quinn criter. & 1.847309 \\
F-statistic & 16.60485 & Durbin-Watson stat" & 1.195933 \\
Prob(F-statistic)" & 0.00000 & &
\end{tabular}

\section{Conclusion}

This analysis is intended to research the effects of the commercial banks' profitability in India from 2008 to 2017. Descriptive analysis, matrix of correlation matrix, and multiple regression analysis were used in the research. The results indicated that the size of the business, capital adequacy, deposit and inflation rate have a strong effect on financial results, whereas the gross domestic product (GDP) has no major impact on asset return. The findings also showed that corporate size (LOGAS), capital adequacy (CA) and deposit (DP) have a negative influence on financial efficiency, whereas macroeconomic characteristics such as gross domestic product (GDP) and inflation rate have a positive effect on the current investigation's return on assets. The present gap in the financial results and productivity of commercial banks in India during the study period is bridged by this paper. For consumers, analysts, investors, academics, and academic researchers, this study is also quite significant. 


\section{References}

1. Abel, S., \& Roux, P. Le. (2016). Determinants of banking sector profitability in Zimbabwe. International Journal of Economics and Financial Issues, 6(3), 845-854.

2. Acaravci, S. K., \& Calim, A. E. (2013). Turkish banking sector 's profitability factors. International Journal of Economics and Financial Issues, 3(1), 27-41.

3. Al-homaidi, E. A., Ahmad, A., Khaled, A. S. D., \& Qaid, M. M. (2019). External factors and banks ' performance : An empirical examination of commercial banks listed on Bombay Stock Exchange (BSE). International Journal of Emerging Technologies and Innovative Research, 6(6), 368-371. https://doi.org/http://doi.one/10.1729/Journal.22618.

4. Masood, O., \& Ashraf, M. (2012). Bank-specific and macroeconomic profitability determinants of Islamic banks: The case of different countries. Qualitative Research in Financial Markets, Vol. 4 No. 2/3, pp. 255-268. https://doi.org/10.1108/17554171211252565.

5. Almaqtari, F. A., Al-Homaidi, E. A., Tabash, M. I., \& Farhan, N. H. (2019). The determinants of profitability of Indian commercial banks: A panel data approach. International Journal of Finance and Economics, 24(1), 168-185. https://doi.org/10.1002/ijfe.1655.

6. Husain, A. O., \& Abdullah, A. M. (2008). Bank-specific determinants of profitability: The case of Kuwait. Journal of Economic and Administrative Sciences.

7. Singh, A., \& Sharma, A. K. (2016). An empirical analysis of macroeconomic and bank-specific factors affecting liquidity of Indian banks. Future Business Journal, 2(1), 40-53.

8. Al-Homaidi, E. A., Tabash, M. I., \& Ahmad, A. (2020). The profitability of islamic banks and voluntary disclosure: empirical insights from Yemen. Cogent Economics and Finance, 8(1), 1-22. https://doi.org/10.1080/23322039.2020.1778406.

9. Ghosh, S. (2016). Does productivity and ownership matter for growth ? Evidence from Indian banks. International Journal of Emerging Markets, 11(4). https://doi.org/: http://dx.doi.org/10.1108/IJoEM05-2015-0096.

10. Al-Homaidi, E. A., Tabash, M. I., Allamy, K. K., \& Ahmad, A. (2020). The extent of voluntary disclosure in the annual reports of Islamic banks: empirical evidence from Yemen. Banks and Bank Systems, 15(1), 167-184. https://doi.org/10.21511/bbs.15(1).2020.16

11. Ilhomovich, S. E. (2009). Factors affecting the performance of foreign bank in Malaysia (Doctoral dissertation, Universiti Utara Malaysia).

12. Al-Homaidi, E. A., Almaqtari, F. A., Yahya, A. T., \& Khaled, A. S. (2020). Internal and external determinants of listed commercial banks' profitability in India: dynamic GMM approach. International Journal of Monetary Economics and Finance, 13(1), 34-67. https://doi.org/10.1504/IJMEF.2020.105333.

13. AL-Omar, H., \& AL-Mutairi, A. (2008). Bank-specific determinants of profitability: The case of Kuwait. Journal of Economic and Administrative Sciences, 24(2), 20-34. https://doi.org/10.1108/10264116200800006.

14. Al-Homaidi, E. A., Tabash, M. I., Farhan, N. H. S., \& Almaqtari, F. A. (2018). Bank-specific and macroeconomic determinants of profitability of Indian commercial banks: A panel data approach. Cogent Economics and Finance, 6(1), 1-26. https://doi.org/10.1080/23322039.2018.1548072.

15. Saona, P. (2016). Intra- and extra-bank determinants of Latin American banks' profitability. International Review of Economics and Finance, 45, 197-214. https://doi.org/10.1016/j.iref.2016.06.004.

16. Homaidi, E. A., Almaqtari, F. A., Ahmad, A., \& Tabash, M. I. (2019). Impact of corporate governance mechanisms on financial performance of hotel companies: Empirical evidence from India. African Journal of Hospitality, Tourism and Leisure, 8(2), 1-21.

17. Shrivastava, R., Sahu, R. K., \& Siddiqui, I. N. (2018). Indian rural market: opportunities and challenges. International Journal Of Advance Research, Ideas And Innovations In Technology (IJARIIT), MBA/105, 403-410.

18. Al-homaidi, E. A., Tabash, M. I., Farhan, N. H., \& Almaqtari, F. A. (2019). The determinants of liquidity of Indian listed commercial banks : A panel data approach. Cogent Economics \& Finance, 7(1), 1-20. https://doi.org/10.1080/23322039.2019.1616521. 
19. Singh, S., Sidhu, J., Joshi, M., \& Kansal, M. (2016). Measuring intellectual capital performance of Indian banks. Managerial Finance, 42(7), 635-655. https://doi.org/10.1108/MF-08-2014-0211.

20. Al-Homaidi, E. A., Tabash, M. I., Al-Ahdal, W. M., Farhan, N. H., \& Khan, S. H. (2020). The liquidity of Indian firms: empirical evidence of 2154 firms. The Journal of Asian Finance, Economics, and Business, 7(1), 19-27.

21. Viswanathan, P. K., Ranganatham, M., \& Balasubramanian, G. (2014). Modeling asset allocation and liability composition for Indian banks. Managerial Finance, 40(7), 700-723. https://doi.org/10.1108/MF-10-2013-0276.

22. Yahya, A. T., Akhtar, A., \& Tabash, M. I. (2014). The impact of political instability, macroeconomic and bank-specific factors on the profitability of Islamic banks: an empirical evidence. Investment Management and Financial Innovations, 14(4), 30-39. 